\title{
Bireyve
}

Toplum

\section{Gezi Eylemlerini ve Gençliğini Anlamak!}

\author{
Kadir CANATAN ${ }^{1}$
}

Öz: Siyasal yönü öne çıkartılan Gezi eylemleri, farklı boyutlarıyla derinlemesine irdelenmesi gereken bir hadisedir. Bu eylemlerin ortaya çıkış ve gelişim sürecinin daha anlaşılır olabilmesi için toplum kesimleri açısından irdelenmesi ayrı bir öneme sahiptir. Kendine has özellikleri olan ve toplumsal hadiselerde farklı roller üstlenen gençlik açısından bu tür hadiselerin ele alınması hem hadisenin daha anlaşılır olmasını sağlayacaktır hem de gençlik hakkında önemli bilgiler verecektir. Bu çalışmada Gezi eylemleri ve bu eylemler üzerinden gençlik farklı bir yaklaşımla ele alınacaktır.

Anahtar Kelimeler: Toplum, gençlik, sosyal hareketler, siyaset, modernite.

\section{Giriş}

Gençlik, sosyolojik anlamda bir grup değil bir kategoridir. Grup olgusunda yüz yüze ilişkiler, ortak paydalar ve ilişkilerde göreceli bir süreklilik esas iken, kategoride istatistiki bir tanımlama yeterlidir. Sözgelimi bir kategori olarak gençlikten bahsederken belirli bir yaş aralığına dâhil olmak yeterli bir kriterdir. Bununla birlikte gençlik, literatürde

1 Prof. Dr., Sabahattin Zaim Üniversitesi Sosyal Hizmet Bölümü Öğretim Üyesi, kadircanatan@yahoo.com 
üzerinde ittifak edilmiş bir kategori değildir. Genç tanımı yapılırken sosyolojik, psikolojik ve biyolojik tanımlar yapılmaktadır. Bundan dolayı, homojen bir gençlik tanımı yapılamamaktadır; gençlik her zaman için tanımlanması oldukça karmaşık ve sorunlu bir kategoridir. Genç grup için farklı yaş aralığının verilmesinin sebebi, gençliğin tanımının tarihsel ve toplumsal olarak değişiklik arz etmesidir. Kimi çalışmalar, 12-24 yaş grubunu, kimi çalışmalar ise $12-26$ yaş grubunu, kimileri ise 15-24 ya da 15-30 yaş grubunu genç olarak ele almaktadırlar. Birleşmiş Milletler (BM), Birleşmiş Milletler Eğitim, Bilim ve Kültür Kurumu (UNESCO) ve Dünya Bankası (WB), 15-24 yaş aralığındaki kişileri "genç" olarak tanımlamaktadır (UNESCO, 2011, World Bank, 2011). Bununla birlikte, UNESCO, genç insanların değişen ve heterojen bir grup olduğunu ve genç olma tecrübesinin bölgelere ve ülkelere göre büyük değişiklik arz ettiğini vurgulamaktadır. İngiliz Milletler Topluluğu Gençlik Programı gibi örgütler, genç kişileri 15-29 yaş aralığındakiler olarak tanımlamakta; Avrupa Birliğinin bazı raporlarında da gençler 15-29 yaş aralığındakiler olarak tanımlanmaktadır (Commission of the European Communities, 2011, Commonwealth Youth Programme, 2011).

Pek çok ülkede olduğu gibi Türkiye'de de bu kategori hakkında konuşmak ve yazmak için yeterli nedenler bulunmaktadır. Her şeyden önce Türkiye toplumu, genç nüfusunun hala çok önemli bir ağırlığa sahip olduğu dinamik bir toplumdur. Eğer 15-29 yaş kesimi gençlik olarak tanımlanırsa, Türkiye nüfusunun yüzde 25 'ini gençlik oluşturmaktadır. İkinci olarak gençlik bir toplumda değişimi anlamada ve geleceği yordamada önemli bir kesimdir. Salt bu nedenle araştırmalar yapılmakta ve değişim yönü üzerinde görüşler belirtilmektedir. Üçüncü olarak gençlik, beklenti ve sorunlarıyla incelenmesi gereken bir kesittir. Gençlerin beklenti ve sorunları anlaşılmadan bir toplumdaki gençlik hareketleri de anlaşılamaz. Bizi de bu makalede ilgilendiren bu son noktadır. 2013 yılının bahar aylarında gerçekleşen Gezi eylemleri, daha sonra gösterileceği üzere bir gençlik hareketidir ve bu eylemi anlamak, ancak bu eyleme damgasını basan gençliğini anlamakla mümkündür.

Gezi eylemlerine katılan gençleri ve bu gençler üzerinden Gezi olaylarını anlamak için ilk önce Türkiye'de gençliğin genel bir profili çizilecek, 
daha sonra Gezi eylemlerine katılan gençlerin bazı özellikleri ve söylemleri irdelenecektir. İlk bölümde, son yıllarda Türkiye'de gençlik üzerine yapılan çalışmalardan faydalanacağız. İkinci bölümde ise, SETA Vakfı tarafından yazılan rapor ile Yıldız Teknik Üniversitesi Eğitim Fakültesi öğrencileriyle yaptığımız anket çalışmasının verilerini kullanacağız.

Türkiye'nin genel gençlik profili ile Gezi eylemlerinin aktörleri olan gençler karşılaştırıldığında bu gençlik hareketinin bazı karakteristik özellikleri ortaya çıkarılmış olacaktır.

\section{Türkiye'nin Gençlik Profili}

Gençliğin profilini çizmede yararlanılacak kriterlerden biri, geleneksel yapıdan hızla uzaklaşan ve dolayısıyla da modernleşen toplumlarda gençlerin gelenek ve modernlik bağlamında kendilerini nasıl konumlandırdıklarıdır. Burada gelenek ve modernlik kavramları tanımlanmadan doğrudan doğruya gençlerin algısına göre ele alınacaktır. Fakat aynı zamanda başka değişkenlerle bağlantılı olarak değerlendirildiğinde gençlerin bu kavramlardan ne anladıkları kısmen açıklığa kavuşacaktır.

SEKAM araştırması, gelenek-modernlik bağlamında gençlerin ezici bir çoğunluğunun (yüzde 72) kendilerini "biraz modern biraz geleneksel” algıladıklarını ortaya çıkarmıştır. Başka bir deyişle kendisini sadece "modern" (yüzde 12) ya da sadece "geleneksel" (yüzde 16) olarak gören gençler azınlıkta kalmaktadır (2013:62). Hızla modernleşen toplumlarda modern kimlik ve geleneksel kimlik arasında her zaman bir çatışma görülür ve bu çatışma, genellikle eski ve yeni kuşaklar arasındaki çatışmayla baş başa gider. Fakat ilgili araştırmanın ortaya çıkardığ bu veri, 2000'li yılların Türkiyesi’nde artık bu çatışmanın anlamsız bir hale geldiği ve söz konusu çatışmanın yeni bir kimlikle, yeni bir aşama kaydettiği anlaşılmaktadır. Bugün gelinen aşamada gençler modern ya da geleneksel değil, melez bir kimlik edinmiş gözükmektedir.

Melez kimlikli gençlerin nerede (köy/kasaba, ilçe ve şehir) yaşadıkları çok önemli olmadığına göre mekânsal/coğrafi anlamda da yaygın bir kimlik olduğuna işaret etmektedir. Eğitim ve ailenin sosyo-ekonomik 
durumu, melez kimliğin oluşumunda fazla etkili gözükmemektedir. Ön-lisans ve lisans eğitimi düzeylerindeki gençlerin oranı kısmen fazladır, ama her eğitim düzeyinde bu kesim yüzde 60 'dan aşağıya düşmemektedir. Çok yoksul olmak ve çok zengin olmak da nispetlerde önemli bir farklılık yaratmamaktadır. Kadınlar nispeten daha fazla oranda kendilerini melez tanımlamaktadır.

Melez olmak, sözgelimi dinle bağlantılı kılındığında ne anlama gelmektedir? Kendilerini "biraz modern, biraz geleneksel” olarak gören insanlara göre din hayatın neresinde durmaktadır? "Dini insan hayatındaki yeri önemlidir" önermesine "Kesinlikle katılıyorum" ve "Kat1lıyorum" diyen melez gençlerin oranı yüzde 86 civarındadır. Kendini salt modern olarak tanımlayan gençlerde ise bu nispet yüzde 66 civarındadır (SEKAM, 2013:73). Demek ki modern olmak, dinin hayattaki rolüne ilişkin düşüncelerde kısmen değişmeye yol açmaktadır. Fakat melez kimliklerde din hala önemini korumaktadır. Bu tarz kimliklerin egemen olduğu modernlik biçimi "muhafazakâr modernlik" olarak tanımlanabilir. Oysa Batılı toplumlarda modernleşme, geleneksellik ile birlikte yürümemiş ve sekülerlikle sonuçlanmıştır.

Gençlerin profilini çizmede önemli bir başka kriter, siyasal ve ideolojik kimlikler bağlamında gençlerin kendilerini tanımlama biçimleridir. Yukarıda sözü edilen araştırmada 18 farklı siyasi, ideolojik ve dini kimlik listesi sunulmuş ve gençlerin bunları kendilerine ne kadar uygun bulup bulmadıkları sorgulanmıştır. Sorgulama sonucunda beş siyasal/ideolojik kimliğin (ÇOK) UYGUN olduğu saptanmıştır: Müslüman (yüzde 95), İlerici (yüzde 83), Atatürkçü (yüzde 83), Laik (yüzde 81) ve İslamcı (yüzde 71) (SEKAM, 2013:99). Müslüman ya da dini kimliğin ilk planda sayılması iki şeye işaret etmektedir. İlk olarak dini kimlik, tüm sekülerleşme iddialarına ve çabalarına rağmen ayakta kalmış ve hatta son yıllarda yeniden cazip hale gelmiştir. İkinci olarak bu kimlik diğerlerinden daha fazla bütünleştirici ve kuşatıcı bir kimlik olarak görünmektedir.

Kimlikleri faktör analizine tabi tuttuğumuzda Atatürkçü, Kemalist, Laik ve İlerici seçeneklerinin birbirlerine yakın düştükleri, Muhafazakâr 
kimliğe ise en uzak oldukları görülmüştür. Yine aynı şekilde Liberal, Sosyal Demokrat, Sosyalist ve Demokrat kimlik seçenekleri birbirine yakın düşerken, Dindar kimlik bunlara en uzak kalmaktadır. İslamcı, Dindar ve Müslüman kimlikleri ise birbirine yakın düşerken, Kemalist, Ateist ve Komünist kimlikleri en uzak düşmektedir.

Bu veriler, Müslüman/Dindar ve Muhafazakâr kimliği ile diğer Seküler kimlikler arasında açık bir mesafe olduğunu göstermektedir. Seküler kimlikler kendi içlerinde iç içe geçmeler yaşarken, Müslüman/ Dindar ve Muhafazakâr kimliği kendilerinden uzak mesafede görmektedirler. Bu demektir ki, Türkiye'de zaman zaman patlak veren din ve laiklik tartışmalarının toplumsal bir temeli bulunmaktadır.

Öte taraftan dini ve seküler kimliklerin birbirleriyle hiç iç içe geçmedikleri söylenemez. Bilakis bu kimlikler iç içe geçen halkalar şeklinde üst üste gelmektedir. Bunun kanıtlarından biri, gençlerin daha somut bir dini pratik olan namazla ilişkileridir. Farklı nispetlerde de olsa her kimlikten belirli bir grup "düzenli” veya "ara sıra” namaz kıldıklarını beyan etmişlerdir. Hatta kendilerini ateist olarak tanımlamalarına rağmen gençlerin yüzde 13 'ü düzenli, yüzde 33 'ü ise ara sıra namaz kıldığını belirtmektedir. Bu oranlar, Atatürkçülerde yüzde 19-50, Devrimcilerde yüzde 13-50, Laiklerde ise yüzde 20-50 dolaylarında gözükmektedir. Bu durumda şöyle bir yorum yapılabilir: Müslümanlık, geleneksek ve otantik bir kimlik iken diğerleri (Atatürkçü, Laik ve İslamcı) daha yeni ve modern kimliklerdir. Gelenek ve modernlik bağlamında ortaya çıkan melez kimlik olgusuyla ideolojik kimlikler arasında bir tutarlılık olduğu anlaşılmaktadır. Çünkü pek çok genç, Müslüman kimlikle diğer modern kimlikleri pekâlâ bağdaştırabilmektedir.

\section{"Gezi gençleri"}

Gezi gençleriyle kastettiğimiz insanlar, 2013 yılının 27-30 Mayısında patlak veren Gezi Parkı eylemlerine katılan gençlik kesitidir. Acaba Gezi eylemlerine katılan gençler, Türkiye'nin gençlik profili içinde nereye oturmaktadır? Motivasyonları ve ideolojik profilleri açısından nasıl bir 
konuma sahipler? Bu sorulara cevap vermeden önce Gezi eylemlerinin genel karakterine kısaca bakmakta fayda var.

Gezi eylemleri, yarı-spontan yarı-örgütlü olarak 2013 yılının Mayıs ayının son günlerinde patlak vermiş, 31 Mayıs-15 Haziran tarihleri arasında siyasallaşmış ve nihayet 15 Haziran sonrasında ise giderek zayıflayarak sona ermiştir. Bu eylemlere katılan insanlar arasında birçok saha araştırması yapılmıştır. Konda ve Metropol gibi kamuoyu araştırma şirketlerinden SETA gibi hükümete yakın düşünce kuruluşu gibi birçok kurum Gezi eylemcilerinin demografik ve siyasal profilini çıkarmaya çalışmışlardır. Bu araştırmalardan anlaşıldığı kadarıyla Gezi eylemlerine katılanların kahir ekseriyetini gençler ve öğrenciler oluşturmaktadır. Sözgelimi Metropol anketine göre eylemlere katılanların yüzde 70'e yakını 20-29 yaş aralığında, Konda'ya göre katılanların yüzde 66'sı öğrenci olduklarını bildirmişlerdir.

Aynı araştırmalarda cinsiyet dağılımının yarı yarıya kadın-erkek şeklinde olduğu saptanmış olup, Metropol öğrencilerin yüzde 54'ünün üniversite öğrencisi, yüzde 20,6'sının üniversite mezunu, yüzde 8,2'sinin ise yüksek lisans ve doktora mezunu oldukları belirlemiştir.

SETA, katılımcıların gelir durumlarıyla ilgili topladığ 1 verilerde şu sonuca ulaşmıştır: "Gelirleri birbirinden çok farklı olan eylemciler bile kendilerini "orta" olarak konumlandırmaktadır... Elbette burada söz konusu olan şey kişilerin nesnel veriler ışı̆̆ında sınıflandırılması değil, sübjektif bakımdan kendilerini nasıl konumlandırdıklarıdır. Ön plana çıkan bulgu, birbirinden çok farklı düzeydeki gelir sahiplerinin bile genel olarak ekonomik durum itibariyle kendilerini aynı pozisyona yerleştirdikleridir. Elbette eylemciler arasında hem ülke bazındaki ekonomik sorunlardan yakınan, hem de bireysel olarak kendisini alt tabakalarda görenler de vardır. Ancak araştırmamızda ön plâna çıkan şey, eylemcilerin genel olarak kendilerini "orta” olarak konumlandırmaya eğilimli olduklarıdır. Bu da sınıfsal veya ekonomik gerekçelerin eylemlerin arkasındaki birincil motifler olmadığını göstermektedir. Zaten mülâkatlarımız kapsamında eylemcilere neden Gezi Parkı eylemlerine katıldıklarını sorduğumuzda, doğrudan ve ilk sırada ülkenin ekonomik 
sorunlarına veya bireysel olarak yaşanan ekonomik sıkıntılara işaret eden olmamıştır. Eylemcilerin sosyo-ekonomik profili, Gezi Parkı olaylarının bir "işçi hareketi” veya Mayıs 1968 olaylarında olduğu gibi gençlik (öğrenci)-işçi koalisyonu bir hareket olmadığını ortaya koymaktadir." (2013:45).

Gezi eylemlerinin durulmasından bir süre sonra Yıldız Teknik Üniversitesi (YTÜ) Eğitim Fakültesi öğrencileriyle yaptığımız araştırmada biz şu sorulara cevap aradık ve bu sorulara verilen cevaplar yoluyla katılımcıların motivasyonlarını ve ideolojik kimliklerini anlamaya çalıştık².

Gezi eylemlerine katıldınız mı? Katıldınızsa bazı özelliklerinizi kaydet istiyorum (Yaş, cinsiyet, eğitim ve meslek gibi)

Gezi eylemlerine nasıl katıldınız (grup olarak mı, yoksa bireysel mi)?

Ne kadar süre eylemlere katılım sağladınız?

Hangi amaçla eylemlere katıldınız?

Sizce amacınıza ulaştınız mı?

Polis ve idareciler yerinde olsaydınız eylemcilere karşı nasıl davranırdınız?

Sizce Gezi olaylarını manipüle eden/istismar eden gruplar var mıydı? Varsa kimlerdi?

Sizce medya mesajınızı doğru iletti mi?

Araştırma, söyleşi tekniğiyle yapıldığı için bu temel sorulara ek olarak yan sorular da sorularak bazı konularda daha detaylı bilgiler derlenmiştir. Araştırmanın yapılma biçimi ve yeri, katılımcıların seçici bir şekilde araştırmaya katılmalarını sağlamıştır. Araştırma grubunda gençler veya öğrenciler ağırlıklı bir grup olmuştur. Ancak bu, diğer araştırma sonuçlarıyla da karşılaştırıldığında önemli bir sorun sayılmaz. Çünkü YTÜ Eğitim Fakültesi öğrencileriyle yaptığımız söyleşilerde ortaya çıkan

22 ve 3 hafta gibi kısa bir süre içinde Gezi eylemlerine katılan eylemcilerle Gezi Parkı etrafında ve öğrenciler arasında söyleşi yaparak Gezi eylemlerini ve gençliğini anlamamıza yardımcı oldukları için Yıldız Teknik Üniversitesi Eğitim Fakültesi Psikolojik Danışmanlık ve Rehberlik ile Sosyal Bilgiler Öğretmenliği 1. Sınıf öğrencilerine teşekkür borçlu olduğumu bildirmek isterim (Kadir CANATAN). 
veriler, diğer araştırma kuruluşlarının verileriyle uyumlu gözükmektedir. Şu halde ilk elden şu saptamaları yapmak mümkündür: Gezi eylemleri, genç ya da öğrenci diyebileceğimiz bir kesimin ağırlıklı olarak katıldığ tirildiğinde görülecektir ki, bu hareket ne sosyal ve ekonomik endişeler ne de öğrenci talepleriyle şekillenmiştir. Öncelikle bir gençlik hareketi olduğu kesindir. Ama bu daha önce Türkiye ve dünyanın tanıdı̆̆ı, gençler ve öğrenciler için özel talepleri olan klasik bir gençlik hareketi de değildir.

Araştırmamızda gençlerin Gezi eylemlerine hem birey hem de grup olarak katıldıkları anlaşılmaktadır. Üniversite öğrencisi bir bayanın şu ifadeleri, eylemlere katılım bireysel olarak başlasa bile zamanla kolektif bir hal alabilen kendi dinamiği olan bir eylem biçimi olduğunu da göstermektedir: "İlk başlarda bireysel olarak oralarda bulundum. Daha sonra tanıştığımız kişilerle beraber grup haline geldik. Sayımız giderek arttı.” Bu ve buna benzer sözler katılımcılar için grup dinamiğinin önemini ortaya koymaktadır. Eylemlere katılanlar kısa bir sürede bir grup psikolojisiyle hareket etmeye ve bu işi eğlenceli bir eyleme dönüştürmeye yönelmişlerdir. Bu grup dinamiği sadece eylem alanında değil, eylem alanına yeni katılımcıların taşınması aşamasında da etkili olmuştur. Bu konuya eylemcilerin taleplerine yönelik analizlerimizde yeniden döneceğiz.

Eylemcilerin farklı sürelerle Gezi Parkı'na gittikleri, ikinci soruya verilen cevaplarda anlaşılmaktadır. Kimisi günlerce alana giderken, kimisi iş ve okul nedeniyle fazla katılım sağlayamadıklarını belirtmişlerdir. Fakat daha önemli olan bir nokta, eylemlerin karakterinin katılım sürelerinde etkili olmuş olmasıdır. Bazıları, eylemlerin şiddete dönüşmesiyle eylemden vazgeçmiştir: "Yaklaşık 4-5 gün eylemlere katıldım diyebilirim. Daha da bulunmak isterdim. Orada polisin bize karşı şiddet ve biber gazıyla davranması beni bayağ site öğrencisi). Bazı kişiler ise, tam tersine bu olayların şiddetlenmesine tepki göstererek sonuna kadar eylemlere katılmışlardır: "Aşırı dozda şiddet kullanıldığı için buna tepki olarak sonuna kadar katıldım” (Erkek, Yüksek Lisans Öğrencisi). 
Güvenlik güçleri ve göstericiler arasında 29 Mayıs gününden itibaren yaşanan çatışmalar, 31 Mayıs akşamı zirveye çıkmıştır. Bu tarihten itibaren güvenlik güçleri ve hükümet yetkililerinin Gezi Parkı olaylarına yönelik tutumunda hızlı bir sertleşme yaşandığı söylenebilir. Eylemcilere, daha sonra tartışmalara neden olan yoğun biber gazı ile müdahale eden Çevik Kuvvet ekipleri, TOMA'lardan sıkılan tazyikli suyun yardımıyla göstericileri Taksim Meydanı’ndan uzaklaştırarak başta İstiklal Caddesi olmak üzere Harbiye, Gümüşsuyu ve Tarlabaşı bölgelerine doğru püskürtmüştür. Beyoğlu bölgesinde yaşanan şiddet olaylarına paralel olarak Ankara ve İzmir gibi büyük kent merkezlerinde ortaya çıkan gösteriler, ilk gösterilerin Gezi Parkı odaklı gündemini daha kapsamlı bir hükümet karşıtı eylem hüviyetine kavuşturmuştur (SETA, 2013:23). Eylemlerin şiddetle çığırından çıkarıldığı ve başka bir şekle doğru zorlandığ 1 açık olmakla birlikte, bu gelişmeyi sadece polisin tutumuyla da açıklamak olası değildir. Çünkü eylemlere çok farklı türden gruplar katılınca, zaten siyasallaşma kaçınılmaz olmuştur. Bir anlamda hükümet karşıtı tüm gruplar olağan koşullarda bir araya gelmesi mümkün olmayan gruplar arasında bir dayanışma ruhu yaratmıştır. Burada da grup psikolojisi ve dinamiğinin etkili olduğu görülmektedir.

Hangi amaçla eylemlere katıldıklarına değin dördüncü soru, söyleşinin en ilginç kısmını oluşturmaktadır. Çünkü bu bağlamda söylenen sözler çok çeşitli olduğu gibi zaman zaman da klişeler halinde biteviye tekrarlanmaktadır. Katılımcıların bir kısmı, Gezi eylemlerinin başında amaçlanan bir fikri destelemek için gittiklerini belirtiyorlar. Bu bağlamda 24 yaşındaki bir öğrenci "Yapılan haksızlıklara ve doğa katliamına karşı katıldım” derken, bir başka öğrenci "Çevrecilik fikrinin yaşatılması için gittim” cevabını vermektedir. Bu bağlamda söylenen sözler genellikle yeşillik, ağaçların ve parkın korunması ve çevreye sahip çıkma etrafında dönerken bazen de bunun tersinden burada tasarlanan projeye karşı ifadelerle pekiştirilmektedir: Betonlaşmaya, kapitalistleşmeye, rant yaratmaya ve avm’ye hayır demek vb.

İkinci bir grup, özellikle polis şiddetini takip eden günlerde eylemlerin amacını "polis şiddetini protesto etme" şeklinde formüle etmektedir. 
"En başta amacımız tabi ki ağaçtı. İstiklalde işyerim var. Burada tek yeşil alan burasıydı. Hali hazırda devam eden hukuki bir süreç vardı. Ama polis meseleyi hukuksuz bir boyuta taşıdı, o andan itibaren bunu protesto etmek için oradaydık. Aynı haksızlıklar bir gün bizim de başımıza gelebilir" (33 yaşında bir erkek, Grafikçi). Polis şiddetini birçok kişi ülkede başlayan yeni bir sürecin göstergesi olarak algılamıştır. Onlardan tarih öğretmeni ve "sosyalist" olduğunu söyleyen bir kişi şu sözleri sarf etmiştir: "Ülkede artan polis şiddeti paralelinde devlet faşizminin her alanda kendini hissettirmesine karşı bedensel ve ruhsal bir duruş sergiledim." Bu grubun klişe sözü hep "Polis şiddetine ve diktatörlüğe karşı sesimizi yükseltmek” olarak ifade edilmiştir. Doğal olarak diktatörlük Başbakan Tayyip Erdoğan'la özdeşleştirilerek bizzat o hedef alınmıştır. Onun polisin tavırlarını onaylayan sözleri, polis şiddetini de onaylandığ 1 şeklinde yorumlanmıştır.

Kimi Kürt ve Alevi grupların kendi kimliklerini vurgulayan sözleri ve kendi hayat tarzlarını hedef alan siyasi uygulamalardan şikâyetçi olmaları, Gezi eylemlerinin bir başka teması olmuştur. "Aynı coğrafyanın insanları olarak haklarımızın yeterince olmadığına inandığım için gittim. Aleviyim ve inancımı tanımayanlar için gittim. Diğer ezilen halklar için gittim.” (20 yaşında erkek üniversite öğrencisi). Başbakanın "dindar nesil" çağrısı da tepkilere konu olmuş ve bazı korkuları harekete geçirmişe benziyor: "Başbakanın devleti şeriata göre yönettiğini düşünüyorum. Bulunduğum liseyi imam hatip lisesine çevrileceğini duydum. Katılma nedenim budur." (14 yaşında erkek lise öğrencisi). "Ülkenin iyi gitmeyen gidişatına bir dur demek için. Eğitim sistemindeki bozukluk, doğuda akan kanı durdurmak için ve iktidar partisine sesimi duyurmak için katıldım. Ben de buradayım demek için.” (19 yaşında öğretmen adayı bir Kürt genci).

Katılımciların ifadelerinden Gezi olaylarının hem bir birikim olduğu hem de grup dinamiğinin etkili olduğu bir eylem olarak anlaşılması gerektiğini ortaya koymaktadır. "Gezi Parkı’na beş arkadaşımla katıldım. Direnişin ilk günleri oradaydık. Amacım hiçbir siyasi partiyi desteklemeden bu halkın da bir dili ve aklı olduğunu göstermek ve 
doğa tahribine izin vermeyeceğimizi göstermekti. Tabi altında bir birikmişlik vardı: Birbirimize düşürülmüşlük, aşağılanmak, topraklarımızın satılmalı, etnik grupların hor görülmesi, dini tekelcilik ve rantç1lık gibi gelişmelere kayıtsız kalmamak.” (Karadeniz Teknik Üniversitesi öğrencisi). "Kendi adıma iki nedenden dolayı katıldım. İlk olarak Gezi Parkı'nda bulunan ağaçların kesilmesine tepki göstermek, ikincisi ise başbakanın sert tutumlarını, din-devlet işlerini birbirine karıştırmasını, yani din üzerinden siyaset yapmasını, baskıcı politikalarını kınamak için oradaydım.” (Üniversitesi Öğrencisi). "Sistemin değişmesi için katıldım” (24 yaşında erkek meslek öğretmeni). Bu ifadeler daha çok hükümet hanesine kaydedilen olumsuz gelişmelerin bu tepkide etkili olduğunu göstermekle kalmıyor, ağaçların kesilmesinin bardağı taşıran son damla olduğunu gösteriyor. Gezi eylemlerini başlatan ünlü bir oyuncunun twitterda takipçilerine söylediği gibi "Mesela sadece Gezi Parkı değildi."(M. Ali Alibora).

Gezi eylemlerine katılma motivasyonu olarak birçok kişinin salt orada bulunanlara destek vermek ya da orada olan biteni (polis şiddetini) protesto etmek amacıyla bulunması grup dinamiği açısından kaydedilmesi gereken önemli bir husustur. Sözgelimi bir baba neden katıldığını şu sözlerle ifade etmiştir: "Kızıma destek olmak için, kızımın geleceği için katıldım.” (49 yaşında erkek). Yine bir başka katılımcı, eylemcilere verdiği desteği şu sözlerle ifade ediyor: "Her başa gelenin keyfi uygulama yapamayacağını anımsatmak ve çorbada tuzum olsun diye katıldım.” (Sade vatandaş). Bu örnekler eylemlere katılan kişilerin mağdur edilmesine bir tepki olduğunu ve eylemin sadece eylemcilerle sınırlı kalmadığını göstermektedir. Eylemler boyunca, çekirdek grubu oluşturan eylemcilerle onları destekleyenlerin iç içe geçmiş iki ana halkadan oluştuğunu göstermektedir.

Gezi eylemlerinin gerçek amaçları üzerine kamuoyu ve siyaset çevrelerinde yapılan tartışmaları, bulgular çerçevesinde değerlendirmek gerekirse olayın indirgemeci bir mantıkla anlaşılamayacağı açıktır. Gezi eylemlerinde pek çok kişi ve grup aktif olmuş ve olaya kendi anlamlarını yüklemeye çalışmışlardır. Olayı kronolojik olarak iki aşamada 
değerlendirmek mümkündür. İlk aşamada çevreci kişi ve gruplar eylemlere hâkim olup Gezi Parkı’nda yapılan çevre tahribatına karşı tepki göstermişler ve buranın AVM'ye dönüştürülmesine itiraz etmişlerdir. İkinci aşamada ise, eylemler siyasallaşmış ve farklı grupların istismarına açık hale gelmiştir. Bu aşamada polislerin ve onlara talimat veren yöneticilerin orantısız şiddet kullanımına müsaade etmeleri, politik grupların direnişini ve kendilerini haklı göstermesine fırsat vermiştir. Bu aşamada, eylemi başlatanlar bile "Mesele sadece Gezi Parkı değil arkadaş, anlasana!” diyerek siyasallaşmasına destek vermişlerdir.

Söyleşilerde yedinci soru ile Gezi eylemlerini manipüle etmek isteyen grupların varlığı ve kimler olduğu yoklanmak istemiştir. Bu soruya verilen cevapları iki grup haline değerlendirmek mümkündür. Bir grup katılımcı bu soruya olumlu cevap vererek eylemlerin marjinal gruplar tarafından amacının dışına çıkarıldığı belirtilmiş ve hatta bunların kimler olduğuna değin isimler verilmiştir. Kendini "sosyalist" olarak niteleyen bir eylemci, bu soruya şöyle bir cevap vermiştir: "Vard1, faşistlikte dünyanın tüm faşistleriyle yarışabilecek ama her nasılsa kendini solcu gören ruhsuz zihniyetler vardı. Örnek olarak TKP diyebilirim." Zikredilen gruplar en fazla PPK'lılar ve bazı Marksist-leninist gruplar olmuştur. Bazıları ise, isim vermekten kaçınmış ve bu tür olaylarda manipülasyonların doğal olduğu vurgulamıştır. "Vardı. Zaten bu yüzden farklı algılamalar ortaya çıktı. Bu durumdan yararlanmak isteyen marjinal gruplar olayın asıl amacını saptırmışlardır." (Öğrenci). Bir grup katılımcı ise grup dinamiğine işaret ederek, marjinal grupların polis şiddetiyle öne çıktığını belirtmektedir. "Yani o grupların adını bilmiyorum. Fakat ilk günlerde değil de, sonra böyle taşkınlıklar oldu. Gezi Park'ında piknik havası vardı. Olaylar İstiklal'de oldu. Polis müdahale edince. Bu gruplar yöneticilerin yanlış tutumu yüzünden ortaya çıktı.” (Erkek, 33 yaşında).

Bir diğer grup ise, olayları manipüle eden grupların olmadığını iddia ederek, bilakis olayların yöneticiler tarafından amacından saptırıldığını söylemişlerdir. Tipik bir örnek olarak öğretmen adayı olan bir eylemcinin şu sözleri verilebilir: "Evet vardı. Bunlar polisler ve medyadır. Sivil polisler aramıza sızıp medya aracılığıyla bizi kitlelere yanlış 
tanıttılar. Direnişçi kılığında aramıza giren polisler etraftaki esnaflara taş ve molotof gibi şiddet unsurlarıyla saldırdılar. Bunu bizzat kendi gözümle gördüm.” Bu ve benzer ifadelere yer veren eylemciler marjinal grupların varlığını kategorik olarak reddetmişler ve eylemlerin amacının yöneticiler ve bazı karanlık güçlerce saptırıldığını iddia etmişlerdir.

Söyleşilerde, "Polis ve yöneticilerin yerinde olsaydınız nasıl davranırdınız?” sorusu eylemcilerin empati yeteneğini ve karşı tarafı algılama biçimlerini anlamak için yöneltilmiştir. Bu soruya birçok eylemci, "Eylemcileri anlamak ve hatta onlarla dayanışma içinde olurdum" şeklinde cevaplar verirken, bazıları da "Onlar yapması gerekeni yaptılar. Polisler, neticede emir kuludurlar. Yöneticilerin talimatlarını uygulamak zorundaydılar" demiştir. Bazıları ise, "Bu ortamda yönetici olmak istemezdim. Olursam da haksızlıklara karşı eylemcilerden yana tavır koyardım. Hatta gerekirse istifa ederdim" diyerek hem polislerin görev zorluğuna hem de körü körüne talimatlara itaat etmelerine tepki göstermiştir.

Gezi olaylarında medyanın rolü neydi? Eylemciler, medyanın rolünü nasıl tanımlıyorlardı?

Söyleşilere katılan eylemcilerin hemen hemen tamamına yakını, medyanın kendi mesajlarını doğru iletmediğini ve hatta saptırıcı haberler yaptıklarını iddia etmişlerdir. Bazı örneklerle yetiniyoruz: "Bana göre Türk halkının yüzde ellisi saftır. Bunun en önemli kanıtı medyadır. Bu yüzde elli kısmı, medya yoluyla istediğin şekle sokabilirsin. İktidar partisi de bunun farkında olup medya aracılığıyla insanları kullanmaktadır. Bu Gezi Parkı olaylarında da böyle oldu. Yüzlerce kanaldan sadece birkaç tanesi objektif yayın yaptı." (Öğretmen adayı). "Yandaş medyanın yayıldığı bir ülkede sizce bu mümkün mü? Sesini yükselten hapse atılıyor. Yazan çizeni hapse attılar. Gazeteler sansürleniyor. Televizyon kanalları kapatılıyor. Yorumu size bırakıyorum." (Öğrenci). "Medya ve tüm iletişim araçları iktidarın komutu altındaydı. Sosyal medya hiç özgür olmadı." Bu ve benzer ifadelerden eylemcilerin kendi mesajlarını yansıtma konusunda medyanın objektif olamadığına dair geniş bir uzlaşı bulunmaktadır. Gerekçe olarak ise, medya üzerinde iktidarın sıkı bir denetim kurduğu iddiasına sık sık yer verilmektedir. 
Medyanın rolü konusundaki soru, eylemcilerin medya davranışları ve muhtemel siyasal görüşleri konusunda ilginç ve beklenmeyen sonuçlar vermiştir. Katılımcılar sık sık "bazı objektif yayın yapan medya hariç" diyerek bir kısım medyayı "yandaş medya"dan titizlikle ayırt etmişler ve bu medyanın kimliği konusunda bilgiler vermişlerdir. Bir örnek vermek gerekirse: "Bizi doğru anlatmadılar. Halk TV ve Ulusal TV d1şında Gezi'yi doğru bir şekilde anlatan kanal olmadı. Hepsi hükümet yanlısı politika izledi." (24 yaşında meslek öğretmeni).

Medya sorusu, eylemcilerin politik kimliğini ve siyasal sosyalleşme süreçlerini de açığa çıkarmıştır. Verilen yanıtlardan eylemcilerin tipik CHP'li ve ulusalcı ailelerden geldikleri ve düzenli olarak ilgili kanalları izledikleri anlaşılmaktadır. Onlara göre iki kanal dışındaki tüm diğer kanallar "yandaş" olup hiçbir olayı objektif olarak yansıtmamaktadır. Gezi olaylarını da bu iki kanal hariç doğru olarak iletememişler ve hükümet yanlısı politikalarıyla binlerce insanın katıldığ "marjinal” ve "diş destekli” göstermeye çaba sarf etmişlerdir.

Politik kimlik konusundaki bu yargılarımız Metropoll tarafından yapılan araştırma bulgularıyla paralellik arz etmektedir. Söz konusu araştırmaya katılanların yüzde 42'ye yakın kendisini CHP'li, yüzde 10'a yakını BDP'li, yüzde 8,5’i ESP'li, yüzde 7'si TKP'li, yüzde 5,3'ü TGB'li ve MHP'li, yüzde 3,2'i SDP'li ve ÖDP’li olarak nitelemişlerdir. Geriye kalan yüzde 16’lık bir kesim ise ayrıştırılmamıştır (2013:8).

Gezi eylemleri amacına ulaştı mı? Bu soruya, eylemcilerin farklı beklentileri dikkate alınırsa tek yönlü bir cevap vermeleri beklenemezdi. Nitekim verilen cevaplar da oldukça çeşitli olmuştur. Bazı örnekler: "Amacıma ulaşamadım. Çünkü halk isyanı politiklikten uzaklaştı. Özellikle son iki hafta salt eğlence olsun diye gelen insan sayısında büyük artış olmuştur." (Meslek öğretmeni). "Amacımıza ulaştık. En azından iktidar bir taşı kımıldattığı zaman bile iki defa düşünecek. Sorunun yıllarca halkta değil, devlette olduğu görüldü." (18 yaşında öğrenci). "Sonuçta yapılan bir şeyler var ki, millet sokaklara döküldü ve 81 ilde gösteri yapıldı. Demek bir şeyler var ve bir şeyler dönüyor memlekette. Sesimizi olduğunca duyurmaya çalıştık. Günlerce orada kaldık. Ama devlet sesimizi kesmeyi ne yazık ki başardı." (Öğrenci). 
Katılımcların çoğu, tam olarak amaçlarına ulaşmasalar da hükümeti sarstıklarını ve bir daha hükümetin kolay kolay keyfi uygulamalara girişemeyeceğini düşünmektedir. Bir kısmı ise, hükümetin otoriter ve diktatör tavrından hiç vazgeçmediğini ve halkı sindirdiğini iddia etmiştir. Fakat ulaşılan sonuçlar konusundaki fikirler ne olursa olsun bizzat olayların görkeminin herkesi çarptığı ve salt bu nedenle haklı olduğunu düşünenlerin çoğunlukta olduğu gözlemlenmektedir. "Eğer bu kadar insan günlerce hükümete direniş sergilemiş ve olaylar bu kadar yaygın bir hale gelmişse demek ki ortada bir şeyler var” söylemi genel geçer hale gelmiştir.

\section{Sonuçlar}

Gerek önceki kamuoyu araştırmaları gerekse kendi yaptığımız araştırma, Gezi eylemlerinin politik boyutu ağır basan bir gençlik hareketi olduğunu göstermektedir. Gezi Parkı’nı yayalaştırma projesi, eylemleri tetiklemek için bir gerekçe olarak kullanılmış ve AKP iktidarının üç dönemi boyunca oluşan muhalif toplumsal birikim açı bir protestoya dönüştürülmüştür. Eylemi başlatanlardan ve önemli aktörlerden birinin yerinde tespitiyle "Mesele sadece ağaç meselesi değil"dir.

İkinci olarak söz konusu gençlik hareketi, sol veya sosyal demokrat kimlikli gençlerin ağırlıklı olduğu bir harekettir. Bu kimliğin dışında da katılımlar olduğu bir gerçek olmakla birlikte harekete ana karakterini verenler onlar olmamıştır. Öyleyse bu makalede sorguladığımız soruya (yani Gezi gençlerinin Türkiye gençliği içinde nereye oturduğu) şu cevabı verebiliriz: SEKAM araştırmasında kimliklerin faktör analizine tabi tutulmasıyla ortaya çıkarılmış olan üç kimlik grubundan (muhafazakâr ve dindar kimlikler hariç) ikisi Gezi eylemlerine damgasını vuran kimlikler olmuşlardır. Bunlar bir grup kendilerini "Atatürkçü", "Kemalist", "Laik" ve "İlerici" etiketleriyle ifade ederken, diğer grup da "Sosyal Demokrat" ve "Sosyalist" etiketiyle ifade etmektedir. İkinci grubun içinde mütalaa edilmesi gereken "Liberal" ve "Demokrat" kimlikli gençlerin bu eylemlere katıldıkları pek dile getirilmemiştir ve bizim araştırmamızda da bu yönde ipuçlarına rastlanmamıştır. Her ne 
kadar bu kimlikler hayat tarzları bakımından benzer ve ortak paydalara sahip olsalar da eylemlerde pek fazla varlık göstermemişlerdir. Bu da AKP hükümeti ile liberaller ve (sol tandanslı olmayan) demokratlar arasında var olduğu söylenen ittifakın bir teyidi olarak yorumlanabilir.

Söz konusu gençlerin medya davranışları ve siyasal sosyalleşmeleri açısından tek yanlı bir süreçten geçtikleri ve belirli kanallar dışında kalan diğer kanalları kategorik olarak "yandaş medya” dışladıkları görülmektedir. Bu tip bir sosyalleşme de gençlerin dünyaya algılamalarında etkili olmuş ve ufuklarını ciddi anlamda belirlemiştir.

\section{Kaynakça}

KONDA (2103), Gezi Parkı Araştırması, İstanbul.

METROPOLL (2013), Gezi Parkı Protestoları, Ankara.

SEKAM (2013), Türkiye’de Gençlik, İstanbul.

SETA (2013), Kurgu ve Gerçek Arasında Gezi Eylemleri, Ankara.

Abstract: -Understanding Gezi Youth and Gezi Actions- Political dimension of the Gezi actions have been highlighted but these events have to be analysed in every dimensions. It is important to investigate the events from the perspectives of different social groups in order to make clear the origin and the evolution of the Gezi events. These events have sui generis aspects, and analyzing these events will help us to understand the reasons behind the case as well as the youth. In this research, Gezi actions and the yogh that take part in these actions will be handled in different aspects.

Key words: Society, youth, social movements, politics, modernity. 